Original Research Paper

\title{
Prophylactic use of Antibiotics is Essential for Fattening Pig Production?
}

\author{
${ }^{1}$ Túlio Otávio de Araújo Lima Neto, \\ ${ }^{2}$ Letícia Mendonça Rodrigues, ${ }^{3}$ Vitor de Oliveira Araújo, ${ }^{4}$ Hebert Silveira, \\ ${ }^{2}$ Vinicíus de Souza Cantarelli and ${ }^{5}$ Cesar Augusto Pospissil Garbossa \\ ${ }^{1}$ Federal Institute of Education, Science and Technology Southeast of Minas Gerais, Rio Pomba, Brazil \\ ${ }^{2}$ Department of Animal Science, Federal University of Lavras, Lavras, Brazil \\ ${ }^{3}$ Department of Animal Science, Federal Rural University of Amazon, Paragominas, Brazil \\ ${ }^{4}$ Agroceres Multimix, Rio Claro, Brazil \\ ${ }^{5}$ Department of Animal Nutrition and Production, University of São Paulo, Pirassununga, Brazil
}

\author{
Article history \\ Received: 30-04-2018 \\ Revised: 04-05-2018 \\ Accepted: 10-07-2018 \\ Corresponding Author: \\ Cesar Augusto Pospissil \\ Garbossa \\ Department of Animal \\ Nutrition and Production, \\ School of Veterinary Medicine \\ and Animal Sciences, \\ University of São Paulo, \\ Pirassununga, SP 13635-900, \\ Brazil \\ Email: cgarbossa@hotmail.com
}

\begin{abstract}
The demand for animal protein is a fact of relevance for the production systems, especially pork, the most consumed animal protein source in the world. In this sense to ensure the efficient production during the pigs raising the use of Prophylactic Antibiotics (PA) is a common practice, but there is a great potential for the occurrence of resistance to antibiotics. However, the use of PA may not be necessary for certain groups of pigs for example with high sanitary status within the production system. The study lasted for 76 days. Seventy-two barrows at 63 days of age with initial weight of $26.11 \pm 3.55 \mathrm{~kg}$ were used. Two treatments were performed, without the use of prophylactic antibiotics or with the use for five days, being given at 63 days of age with Doxycycline and at 105 days of age with Tiamulin. PA use worsened ADG $(p=0.035)$ by $5.0 \%$ and body weight by $3.0 \%(p=0.039)$ of pigs at 105 days of age when compared to pigs that did not receive Doxycycline. After the second use of PA the pigs at 117 days of age which received Tiamulin presented better ADG of $7.0 \%(p=0.035)$ and a greater body weight of $1.2 \%(p=0.038)$ compared to control group. The animals of the control group presented $6.0 \%$ greater loin depth $(\mathrm{p}=$ 0.023 ) than the animals that received the PA, however pigs of the PA group presented greater hot carcass weight of $0.6 \%(\mathrm{p}=0.005)$ and greater carcass compactness of $2.4 \%(p=0.004)$ compared to the control group. The use of PA should be studied with caution and in a holistic way, considering the sanitary characteristics of management to verify if its use is really justified, as observed in the present study if used in inopportune moments its use can impair the performance of the pigs.
\end{abstract}

Keywords: Swine, Doxycycline, Tiamulin, Metaphylatic

\section{Introduction}

The global population is projected to reach 9.8 billion by 2050 (UN, 2017). This will increase demand for high-quality animal protein and will require the development of strategies to optimize pig production and maintain animal health.

Pig farms have undergone several changes and advances in the way of production, to reach current levels in terms of productive performance, these advances were mainly in sanitation, management, genetics and nutrition (Gavioli, 2012). The high demand of animals for the market tends to force producers to increase the population density of the animals, consequently there is an increase in the health challenge as well as in the number of infectious diseases that cause problems in the productive performance of the pigs. Factors such as various management technologies and sanitary control tend to improve productive efficiency. 
Antibiotics are non-nutritional additives, which means that they do not provide additional feed to the pigs and their absence will not result in nutritional deficiency (Jacela et al., 2010). They are included in the diet only for therapeutic action or for their ability to promote growth of the pigs. The use of antibiotics in prophylactic form aims to improve the performance and health status of pigs. Programs that include polymyxins, tetracyclines and macrolides are widely used. However, according to experts, the overall use of antibiotics by animals is double that of humans (Aarestrup, 2012). In 2010, global consumption of antibiotics for production animals was estimated at 63,151 $( \pm 1,560)$ tonnes and projected to increase $67 \%$ by 2030 , reaching 105,596 $( \pm 3,605)$ tonnes (Van Boeckel et al., 2015). According to the same authors, the specie that has the highest consumption of antibiotics is swine, being $16 \%$ higher than that of poultry and $282 \%$ higher than that of cattle.

Unfortunately, despite the great benefits of antibiotics, there is potential for the emergence of antimicrobial resistance in human pathogenic bacteria (Aarestrup et al., 2008), compromising the therapeutic efficacy of antibiotics in veterinary and human medicine. Antibiotic resistance causes more than 25,000 deaths annually in the European Union and costs approximately 1.5 billion euros. In 2014 it was identified as a major threat to global health and in September 2016 United Nations unanimously declared resistance as one of the world's major health threats (Gonzalez-Zorn and Ortega, 2017).

Therefore, the objective of this study was to evaluate the real need the use of prophylactic antibiotic programs on performance improvement and carcass characteristics of pigs of high sanitary status.

\section{Material and Methods}

Animal procedures were consistent with the Guide for the Care and Use of Animals in Agricultural Research and Teaching (FASS, 2010).

\section{Animals and Facilities}

The trial was conducted at the Experimental Center of Swine (CES) Department of Animal Science of the Federal University of Lavras, in Lavras (MG), from November 5, 2014 to January 20, 2015.

The seventy-two heaviest pigs from a group containing 210 barrows from a commercial line of high genetic potential at 63 days of age were selected. These pigs had a mean initial weight of $26.11 \pm 3.55 \mathrm{~kg}$, being considered high sanitary animals for their better performance.

The pigs were housed in the growing-finishing barn, composed of 24 pens, with dimensions of $1.70 \times 1.80 \mathrm{~m}$, with semiautomatic feeder and nipple drinker, where they remained for 76 days. The temperature was measured using a thermo-hygrometer and the mean recorded was $25.4 \pm 6^{\circ} \mathrm{C}$.

\section{Experimental Design}

The trial was carried out in a randomized complete block design, with initial weight being used as a block factor, with two treatments (Control - No use of prophylactic antibiotics; PA - Use of prophylactic antibiotics) with 12 replicates for performance (represented by the pen consisting of three animals). For carcass traits, a randomized complete block design was used, where the initial weight was used as a block factor, the experimental plot was represented by each animal, totaling 36 replicates per treatment.

The experimental diet (Table 1) was formulated based on corn and soybean meal, following the recommendations described in the Brazilian tables for poultry and swine (Rostagno et al., 2011).

The experiment lasted for 76 days and the animals were fed ad libitum during the whole period. The prophylactic antibiotic treatment was divided into two different phases of the experiment. The first treatment was performed at the beginning of the growth phase with the antibiotic Doxycycline at a dosage of $10 \mathrm{mg} / \mathrm{kg}$ body weight per day for five days. The second treatment was at the beginning of the finishing phase with the antibiotic Tiamulin at a dosage of $8.8 \mathrm{mg} / \mathrm{kg}$ body weight per day for five days. Antibiotics were included in the diets in substitution of the inert Kaolin.

\section{Performance Variables}

The pigs were weighed at the beginning of the experiment, at the end of the growth phase 1 (105 days of age), at the end of the growth phase 2 (117 days of age) and at the end of the finishing phase (139 days of age), for determination of the Average Daily weight Gain (ADG). The feeds provided and the wastage were weighed for the determination of Average Daily Feed Intake consumption (ADFI). Feed Conversion Rate (FCR) was obtained through the relationship between ADFI and ADG.

\section{Carcass Variables}

At the end of the growth phase 2 and at the end of the finishing phase, the measurements of Backfat Thickness (BT), Loin Depth (LD) and Loin Eye Area (LEA) were evaluated by ultrasound ALOKA model SSD-500 and a $3.5 \mathrm{MHz}$ linear transducer model UST 5011. Measurements were performed at $6.5 \mathrm{~cm}$ from the dorsal-lumbar line and $6.5 \mathrm{~cm}$ from the last rib in the cranial direction, at point $\mathrm{P} 2$. At the end of the trial the pigs were sent to slaughter, in a slaughtehouser certified by the Federal Inspection System of Brazil. 
Table 1: Composição das rações formuladas para suínos em crescimento e terminação segundo as recomendações de Rostagno (2011)

\begin{tabular}{|c|c|c|c|}
\hline Ingredients & Grower 1 & Grower 2 & Finisher \\
\hline Maize & 71.000 & 75.661 & 76.223 \\
\hline Soybean meal & 24.830 & 20.937 & 19.889 \\
\hline Soybean oil & 0.909 & 0.513 & 0.926 \\
\hline Dicalcium phosphate & 1.156 & 0.857 & 0.765 \\
\hline Limestone & 0.693 & 0.596 & 0.563 \\
\hline Salt & 0.405 & 0.380 & 0.355 \\
\hline Vitamin premix $x^{\mathrm{a}, \mathrm{b}}$ & 0.250 & 0.250 & 0.250 \\
\hline Mineral premix ${ }^{\mathrm{c}}$ & 0.300 & 0.300 & 0.300 \\
\hline DL-Methionine 99 & 0.054 & 0.024 & 0.090 \\
\hline L-Lysine 54.6 & 0.309 & 0.194 & 0.472 \\
\hline L-Threonine 98 & 0.034 & 0.014 & 0.099 \\
\hline Kaolin & 0.060 & 0.270 & 0.020 \\
\hline Ractopamine $^{\mathrm{d}}$ & 0.000 & 0.000 & 0.050 \\
\hline Total & 100.000 & 100.000 & 100.000 \\
\hline \multicolumn{4}{|l|}{ Calculated composition } \\
\hline Metabolizable energy $(\mathrm{kcal} / \mathrm{kg})$ & 3230.000 & 3230.000 & 3250.000 \\
\hline Crude protein $(\%)$ & 16.820 & 15.430 & 15.000 \\
\hline Digestible Lysine (\%) & 0.927 & 0.823 & 0.900 \\
\hline Digestible Methionine(\%) & 0.292 & 0.247 & 0.306 \\
\hline Digestible Methionine+ Cystine (\%) & 0.547 & 0.486 & 0.458 \\
\hline Threoninedigestible (\%) & 0.603 & 0.535 & 0.603 \\
\hline Calcium $(\%)$ & 0.630 & 0.512 & 0.474 \\
\hline Available phosphorus (\%) & 0.311 & 0.250 & 0.231 \\
\hline Sodium $(\%)$ & 0.180 & 0.170 & 0.160 \\
\hline
\end{tabular}

${ }^{\mathrm{a}}$ Vitamin premix (Grower 1 and 2) containing per of product: Folic acid, $73 \mathrm{mg}$; Pantothenic acid, 3,335 mg; Biotin, $20 \mathrm{mg}$; Choline, $55 \mathrm{mg}$; Niacin, 6,670 mg; Selenium, $100 \mathrm{mg}$; Vitamin A, 1,334,000 IU; Vitamin B1, $240 \mathrm{mg}$; Vitamin B12, 480 mcg; Vitamin B2, 733 mg; Vitamin B6, 400 mg; Vitamin D3, 333,500 IU; Vitamin E, 7,470 UI; Vitamin K3, 733 mg; ${ }^{b}$ Vitamin premix (Finisher) containing per of product: Folic acid, $55 \mathrm{mg}$; Pantothenic acid, 2,500 mg; Biotin, $15 \mathrm{mg}$; Choline, $33 \mathrm{mg}$; Niacin, 5,00 mg; Selenium, 75 mg; Vitamin A, 1,000,000 UI; Vitamin B1, 180 mg; Vitamin B12, 360 mcg; Vitamin B2, 550 mg; Vitamin B6, 301 mg; Vitamin D3, 250,000 IU; Vitamin E, 5,600 IU; Vitamin K3, $550 \mathrm{mg}$; ${ }^{\mathrm{c} M i n e r a l ~ p r e m i x ~ c o n t a i n i n g ~ p e r ~ o f ~ p r o d u c t: ~ C o b a l t, ~} 150 \mathrm{mg}$; Copper, 70 g; Iron, $40 \mathrm{~g}$; Iodine, $750 \mathrm{mg}$; Manganese, $25 \mathrm{~g}$; Zinc, $60 \mathrm{~g}$; ${ }^{\mathrm{d}}$ Ractopamine hydrochloride (2,05\%).

Carcass were weighed after evisceration to determine the hot carcass weight (HCW) and the dressing percentage (DP) was calculated. The carcass length (CL) was mesuared and carcass compactness (CC) calculated through the ratio between $\mathrm{HCW}$ and $\mathrm{CL}$, the determination of the meat yield in the chilled carcass (MYCC) and the bonus index (BI) were also estimated by equations proposed by Guidoni (2000):

$$
\begin{aligned}
& \text { MYCC }=65.92-(0.685 \times B T) \\
& +(0.094 \times L D)-(0.026 \times H C W) \\
& B I=23.6+0.286^{*} H C W+M Y C C
\end{aligned}
$$

\section{Where:}

MYCC $=$ Meat yield in the chilled carcass $(\%)$

$B T=$ Backfat thickness $(\mathrm{mm})$

$L D=$ Loin depth $(\mathrm{mm})$

$H C W=$ Warm carcass weight $(\mathrm{kg})$

$B I=$ Bonification index

The temperature and $\mathrm{pH}$ were measured on the Longissimus dorsi muscle of the left half carcass at the $12^{\text {th }}$ rib height, $45 \mathrm{~min}$ after slaughter. These parameters were measured using the Testo 205 thermometer (Testo do Brasil, Campinas - SP).

\section{Statistical Analysis}

All variables measured were tested for normality by the Shapiro-Wilk test before analysis and any variable that failed to follow a normal distribution was transformed through the RANK procedure of SAS (2002-2008). The PROC RANK statement with the NORMAL option was used to produce a normalized transformed variable. All data were analyzed using the MIXED procedure of SAS (2002-2008) as a randomized complete block design (initial weight). For performance pen was considered as the experimental unit, for the carcass parameters each animal was used as an experimental unit. The effects of the treatments were compared by F test. All data are reported as least square means and the greatest Standard Errors (SEM) were reported. Results are considered significant if $p<0.05$.

\section{Results}

The results of performance are presented in Table 2 . There was no statistical difference $(p>0.05)$ for ADFI and 
FCR in any of the evaluated periods. For the period from 63 to 105 days of age, the pigs in the control group presented greater $(\mathrm{p}<0.05) \mathrm{ADG}$ approximately $5.0 \%$ compared to the animals of the PA group, consequently the live weight of the animals was $2.9 \%$ greater. At this time the animals had only received Doxycycline treatment.

For the period from 105 to 117 days of age, which the pigs of the PA group received the second prophylactic treatment with Tiamulin, a greater ADG of $7.0 \%$ and a superior body weight of $1.1 \%$ was verified for this pigs at 117 days of age compared to the pigs of the control group.
Considering the periods of 117 to 139 days of age and the entire experimental period (63 to 139 days of age), no significant effects $(\mathrm{p}>0.05)$ on the performance was observed.

The variables of Backfat Thickness (BT), Loin Depth (LD), Loin Eye Area (LEA), Hot Carcass Weight (HCW), Carcass Length (CL), carcass Dressing Percentage (DP), Carcass Compactness (CC), Meat Yield in the Chilled Carcass (MYCC), bonus index (BI) and $\mathrm{pH}$ and temperature of the Longissimus dorsi muscle, are presented in Table 3.

Table 2: Performance of high health status barrows on different days of age, receiving or not prophylactic antibiotics

\begin{tabular}{|c|c|c|c|c|}
\hline \multirow[b]{2}{*}{ Variable } & \multicolumn{2}{|c|}{ Treatment } & \multirow[b]{2}{*}{ CV (\%) } & \multirow[b]{2}{*}{ Pvalue } \\
\hline & Control & Prophylactic antibiotic & & \\
\hline Initial weight (kg) & 26.10 & 26.11 & 6.76 & 0.399 \\
\hline \multicolumn{5}{|l|}{63 to 105 days of age } \\
\hline Average daily gain (kg) & 0.95 & 0.91 & 5.86 & 0.035 \\
\hline Average daily feed intake $(\mathrm{kg})$ & 2.07 & 2.05 & 6.59 & 0.588 \\
\hline Feed conversion rate & 2.18 & 2.25 & 5.09 & 0.134 \\
\hline Weight a 105 days of age $(\mathrm{kg})$ & 66.15 & 64.23 & 5.41 & 0.039 \\
\hline \multicolumn{5}{|l|}{105 to 117 days of age } \\
\hline Average daily gain (kg) & 1.00 & 1.07 & 9.94 & 0.038 \\
\hline Average daily feed intake $(\mathrm{kg})$ & 2.32 & 2.35 & 5.73 & 0.582 \\
\hline Feed conversion rate & 2.21 & 2.25 & 11.77 & 0.563 \\
\hline Weight a 117 days of age $(\mathrm{kg})$ & 77.16 & 78.00 & 5.10 & 0.038 \\
\hline \multicolumn{5}{|l|}{117 to 139 days of age } \\
\hline Average daily gain (kg) & 1.15 & 1.16 & 9.66 & 0.903 \\
\hline Average daily feed intake $(\mathrm{kg})$ & 2.99 & 2.90 & 8.21 & 0.419 \\
\hline Feed conversion rate & 2.60 & 2.53 & 9.14 & 0.485 \\
\hline \multicolumn{5}{|l|}{63 to 139 davs of age } \\
\hline Average daily gain $(\mathrm{kg})$ & 1.02 & 1.00 & 4.83 & 0.380 \\
\hline Average daily feed intake $(\mathrm{kg})$ & 2.60 & 2.53 & 5.87 & 0.485 \\
\hline Feed conversion rate & 2.33 & 2.34 & 4.35 & 0.849 \\
\hline Weight a 139 days of age $(\mathrm{kg})$ & 102.66 & 102.49 & 4.37 & 0.919 \\
\hline
\end{tabular}

Table 3: Carcass evaluation performed on different days of experiment in high health status barrows receiving or not prophylactic antibiotics

\begin{tabular}{|c|c|c|c|c|}
\hline \multirow[b]{2}{*}{ Variable } & \multicolumn{4}{|c|}{ Treatment } \\
\hline & Control & Prophylactic antibiotic & $\mathrm{CV}(\%)$ & P Value \\
\hline \multicolumn{5}{|l|}{117 days of age } \\
\hline Backfat thickness (mm) & 4.09 & 3.92 & 36.35 & 0.653 \\
\hline Loin depth (mm) & 41.07 & 40.15 & 10.78 & 0.351 \\
\hline Loin eye area $\left(\mathrm{mm}^{2}\right)$ & 34.64 & 34.99 & 15.06 & 0.613 \\
\hline \multicolumn{5}{|l|}{139 days of age } \\
\hline Backfat thickness (mm) & 5.36 & 5.92 & 31.54 & 0.174 \\
\hline Loin depth (mm) & 47.91 & 45.19 & 11.93 & 0.023 \\
\hline Loin eye area $\left(\mathrm{mm}^{2}\right)$ & 55.21 & 52.73 & 13.78 & 0.176 \\
\hline \multicolumn{5}{|l|}{ After slaughter } \\
\hline Hot carcass weight (kg) & 80.18 & 80.67 & 6.79 & 0.005 \\
\hline $\mathrm{pH}$ & 6.00 & 5.93 & 5.30 & 0.227 \\
\hline Temperature $\left({ }^{\circ} \mathrm{C}\right)$ & 40.51 & 40.77 & 1.41 & 0.065 \\
\hline Carcass length (cm) & 93.80 & 92.77 & 3.05 & 0.112 \\
\hline Dressing percentage & 78.18 & 78.19 & 1.28 & 0.543 \\
\hline Carcass compactness & 0.85 & 0.87 & 6.86 & 0.004 \\
\hline Meat yield in the chilled carcass & 64.68 & 64.18 & 1.93 & 0.105 \\
\hline Bonification index & 111.21 & 110.88 & 1.74 & 0.300 \\
\hline
\end{tabular}


There were no significant differences $(p>0.05)$ for BT, LD and LEA, measured at 117 days of age. At 139 days of age, the pigs of the control group had greater LD of $6.0 \%$ compared with the pigs from the PA group. No difference $(\mathrm{p}>0.05)$ was observed for $\mathrm{pH}$, temperature, CL, DP, MYCC and BI. However, the pigs of the PA group had greater $\mathrm{HCW}$ and $\mathrm{CL}$ of $0.6 \%$ and $2.4 \%$, respectively, compared to the pigs of control group.

\section{Discussion}

Antibiotics can eliminate both pathogenic and beneficial bacteria, impairing the balance of the intestinal microbiota (Blaser, 2011), the beneficial bacteria present in the gastrointestinal tract help in the digestion of food, in addition the intestine function not only as the metabolically site of nutrients absorption, but it is also an important immunological organ (Castro and Arntzen, 1993). Thus, close and intermittent contact of the gastrointestinal tract mucosa with the enteric microbiota results in a constant state of controlled physiological inflammation (Ma et al., 2003; Biancone et al., 2002).

In this sense, the gastrointestinal tract dysbiosis caused by doxycycline, which has an action on respiratory and gastrointestinal diseases, may have negatively interfered with the commensal microorganisms of the animals that received it, thus reducing the use of ingested nutrients.

During this initial period of the trial, the infection pressure was low because the available area per $\mathrm{kg}$ of animals was greater, as well as the facilities were clean and empty and the animals came from a group of high sanitary status, reinforcing the concept that in that moment there was no need for prophylactic antibiotic treatment, which would be commonly performed under field conditions.

During the experiment, a higher occurrence of coughs was observed in the animals between 105 and 117 days of age. Therefore, the second prophylactic use of antibiotic with Tiamulin may have favored an improvement in the weight gain of these animals, since this antibiotic act against respiratory infections (Plumb, 2002). Improvement in performance was also observed by Lensch (1980), who evaluated pigs fed with $30 \mathrm{ppm}$ Tiamulin, observed greater weight gain and higher feed efficiency of these animals.

In addition, as the animals grow the available area per $\mathrm{kg}$ of animals is reduced, which may cause behavioral problems, increase plasma glucocorticoid levels and reduce animal welfare (Randolph et al., 1981; Kornegay, 1986; Meunier-Salaun et al., 1987). Other problems associated with reduced space per pig is a lower level of hygiene in pens without slatted floors and consequently higher prevalence of diseases (Whatson, 1985; Maes et al., $2000 ; 2001)$. Thus, the use of prophylactic treatments with antibiotics has a beneficial effect related to the sanitary condition of the environment and the sanitary status of the animals.

The greater loin depth for the pigs of the control group is possibly associated to the fact that these animals presented better weight gain in the period from 63 to 105 days of age, when the characteristic of lean tissue deposition is maximal, as demonstrated by (Wei, 2001).

The greater hot carcass weight of the animals of the PA group may be related to a possible decrease in the weight of their organs, since the final weight of the animals of the two treatments were statistically equal at the end of the experiment. Protein synthesis occurs differently between organs and the intestine is composed of a highly recycled cell tissue. The presence of microorganisms affects the structure, function and protein turnover of intestinal tissues (McBurney, 1994). Thus, animals in the PA group may have had lower intestinal weight.

As a consequence of the fact that no difference was observed in the carcass length and the greater carcass weight of the PA group, a greater carcass compactness was observed, that is, they presented heavier carcasses per unit length, being animals with better carcass characteristics.

Minimizing the use of antibiotics is necessary because, according to Van den Bogaard et al. (2001), the use of antimicrobial substances is considered the most powerful factor contributing to the emergence, selection and dissemination of antibiotic resistant microorganisms and genes in animals and humans. And as shown in the present study no performance and carcass traits were benefited for the pigs receiving the PA treatment.

\section{Conclusion}

The use of prophylactic antibiotics should be evaluated with caution and in a holistic way, considering the sanitary characteristics of management to verify if their use is really justified, as observed in the present study if used at inappropriate times its use may impair the performance of the pigs.

\section{Acknowledgement}

The authors would like to acknowledge the Swine Study Group of UFLA (NESUI) for helping in the implementation of thisfield trial.

\section{Conflict of Interest}

The authors declare that in this study there are noconflicts of interest

\section{Funding Information}

The authors would like to acknowledge AnimalNutri Science and Technology for funding the trial. 


\section{Author's Contributions}

Túlio Otávio de Araújo Lima Neto: Execution of the experiment sampling, records and write part of the manuscript. Gave final approval of the version to be submitted.

Letícia Mendonça Rodrigues: Execution of the experiment sampling and records. Gave final approval of the version to be submitted.

Vitor de Oliveira Araújo: Write part of the manuscript. Gave final approval of the version to be submitted.

Hebert Silveira: Experimental design, execution of the experiment, sampling and records. Gave final approval of the version to be submitted.

Vinicíus de Souza Cantarelli: Experimental design. Gave final approval of the version to be submitted.

Cesar Augusto Pospissil Garbossa: Experimental design, statistical analysis, execution of the experiment sampling, records and writing of the manuscript. Gave final approval of the version to be submitted.

\section{Ethics}

The authors declare there are no ethical issues related to this observational study.

\section{References}

Aarestrup, F., 2012. Sustainable farming: Get pigs off antibiotics. Nature, 486: 465-466.

DOI: $10.1038 / 486465 \mathrm{a}$

Aarestrup, F.M., H.C. Wegener and P. Collignon, 2008. Resistance in bacteria of the food chain: Epidemiology and control strategies. Expert Rev. Anti-Infective Therapy, 6: 733-750. DOI: 10.1586/14787210.6.5.733

Biancone, L., I. Monteleone, G. Del Vecchio Blanco, P. Vavassori and F. Pallone, 2002. Resident bacterial flora and immune system. Digestive Liver Dis., 34: 37-43. DOI: $10.1016 / \mathrm{S} 1590-8658(02) 80162-1$

Blaser, M., 2011. Antibiotic overuse: Stop the killing of beneficial bacteria. Nature, 476: 393-394. DOI: $10.1038 / 476393 a$

Castro, G.A. and C.J. Arntzen, 1993. Immunophysiology of the gut: A research frontier for integrative studies of the common mucosal immune system. Am. J. Physiol.-Gastrointestinal Liver Physiol., 265: G599-610. DOI: 10.1152/ajpgi.1993.265.4.G599

FASS, 2010. Guide for the Care and Use of Agricultural Animals in Research and Teaching. 3rd Edn., Federation of Animal Science Societies, Champaign, IL.

Gavioli, D.F., 2012. Efeitos de promotores de crescimento para suínos sobre o desempenho zootécnico, a qualidade intestinal e a eficiência da biodigestão dos dejetos. MSc Thesis, Universidade Estadual de Londrina, Londrina, Paraná, Brasil.
Gonzalez-Zorn, B. and G.M. Ortega, 2017. Antibiotic resistance: The role of animal production.

Guidoni, A.L., 2000. Melhorias de processos para a tipificação de valorização de carcaças suínas no Brasil. Proceedings of the 1st Conferência Internacional Virtual Sobre Qualidade de Carne Suína, Nov. 16-Dec. 16, EMBRAPA, Brasil, pp: 221-234.

Jacela, J.Y., J.M. Derouchey, M.D. Tokach, R.D. Goodband and J.L. Nelssen et al., 2010. Feed additives for swine: Fact sheetshigh dietary levels of copper and zinc for young pigs and phytase. J. Swine Health Product., 18: 87-91.

Kornegay, E.T., 1986. Stocking density for growingfinishing swine. Proceedings of the Annual Meeting of the American Association of Swine Veterinarians, (ASV' 86), pp: 16-18.

Lensch, J., 1980. Clinical observations and evaluation of Tiamulin feed medication for the prevention of swine dysentery and for the maintenance of weight gains in the presence of swine pneumonia under field conditions. International Pig Veterinary Society, Copenhagen, Denmark.

Ma, D., D. Wolvers, A.M. Stanisz and J. Bienenstock, 2003. Interleukin-10 and nerve growth factor have reciprocal upregulatory effects on intestinal epithelial cells. Am. J. Physiol.-Regulatory Integrative Comparative Physiol., 284: 1323-1239. DOI: 10.1152 /ajpregu.00756.2002

Maes, D.G., H. Deluyker, M. Verdonck, F. Castryck and C. Miry et al., 2001. Non-infectious factors associated with macroscopic and microscopic lung lesions in slaughter pigs from farrow-to-finish herds. Vet. Record, 148: 41-46. DOI: 10.1136/vr.148.2.41

Maes, D., H. Deluyker, M. Verdonck, F. Castryck and C. Miry et al., 2000. Herd factors associated with the seroprevalences of four major respiratory pathogens in slaughter pigs from farrow-to-finish pig herds. Vet. Res., 31: 313-327.

DOI: $10.1051 /$ vetres:2000122

McBurney, M.L., 1994. The gut: Central organ in nutrient requirements and metabolism. Canadian J. Physiol. Pharmacol., 72: 260-265.

DOI: $10.1139 / \mathrm{y} 94-040$

Meunier-Salaun, M.C., M.N. Vantrimponte, A. Raab and R. Dantzer, 1987. Effect of floor area restriction upon performance, behavior and physiology of growingfinishing pigs. J. Anim. Sci., 64: 1371-1377. DOI: $10.2527 /$ jas $1987.6451371 \mathrm{x}$

Plumb, D.C., 2002. Veterinary Drug Handbook. 4th Edn., Iowa State Press, Iowa, ISBN-10: 0-8138-2442-7, pp: 993.

Randolph, J.H., G.L. Cromwell, T.S. Stahly and D.D. Kratzer, 1981. Effects of group size and space allowance on performance and behaviour of swine. J. Anim. Sci., 53: 922-927. DOI: $10.2527 /$ jas $1981.534922 \mathrm{x}$ 
Rostagno, H.S., L.F.T. Albino, J.L. Donzele, P.C. Gomes and R.F. Oliveira et al., 2011. Tabelas Brasileiras Para Aves e Suínos: Composição de Alimentos e Exigências Nutricionais de aves e Suínos. 3rd Edn., Minas Gerais, pp: 252.

SAS, 2002-2008. System for Microsoft windows. Release 9.2 - Standard Edition, SAS Institute Inc., Cary, NC, USA.

UN, 2017. Department of economic and social affairs population division. World population prospects: The 2017 revision. UN Department of Economic and Social Affairs Population Division, USA.

Van Boeckel, T.P., C. Brower, M. Gilbert, B.T. Grenfell and A.S. Levin et al., 2015. Global trends in antimicrobial use in food animals. Proc. National Academy Sci., 112: 5649-5654.

DOI: $10.1073 /$ pnas. 1503141112
Van den Bogaard, A.E., N. London, C. Driessen and E.E. Stobberingh, 2001. Antibiotic resistance of faecal Escherichia coli in poultry, poultry farmers and poultry slaughterers. J. Antimicrobial. Chemotherapy, 47: 763-771. DOI: $10.1093 / \mathrm{jac} / 47.6 .763$

Wei, R., 2001. Determining the lean growth curve for growing finishing pigs from the lysine requirements estimated by using plasma urea nitrogen as a rapid response criterion. PhD Thesis, Iowa State University, Ames, Iowa, USA.

Whatson, T.S., 1985. Development of eliminative behaviour in piglets. Applied Anim. Behav. Sci.. 14: 365-377. DOI: 10.1016/0168-1591(85)90060-7 